\title{
Using a jumping spider fauna inventory (Araneae: Salticidae) as an indicator of their taxonomic diversity in Misiones, Argentina
}

\author{
Gonzalo D. Rubio \\ National Research Council of Argentina (CONICET), Instituto de Biología Subtropical, Universidad Nacional de \\ Misiones (IBS, UNaM), Puerto Iguazú, Misiones, Argentina; grubio@conicet.gov.ar
}

Received 22-VI-2015. C Corrected 14-I-2016. $\quad$ Accepted 16-II-2016.

\begin{abstract}
Faunistic studies, with a taxonomically complete inventory of species, provide an important source of quantitative compiled information for several and specific regions. This information can be used in diversity analysis and has great potential in setting conservation priorities. In this study, I used the relatively well known salticid spider fauna of Misiones to generate Clarke \& Warwick taxonomic diversity indices. For this, information of three ecoregional salticid diversities was obtained and analyzed between Upper Parana Atlantic Forest (UPAF), Araucaria Moist Forest (AMF), and Southern Cone Mesopotamian Savanna (SCMS). Results showed differences between the three ecoregions of the province, mainly Southern savannas regarding the forests of Northern Misiones. Most species were registered in UPAF followed by AMF, however the $\alpha$-taxonomic diversity of salticids was higher in SCMS than in UPAF and AMF. The $\beta$-taxonomic diversity showed that the proportions of shared species between SCMS and UPAF (or and AMF) were the lowest. The high taxonomic dissimilarity among ecoregions is an indication that the three assemblages are distant, showing a variation in their vegetation habitat and/or bioclimatic characteristics as a possible reason. The need to expand with new samples in subsampled or underexplored areas of Misiones remains essential, however this study contributes to information about biodiversity levels of salticid fauna in three ecoregions of Northeast Argentina, and will provide reference data for future studies for management plans. Rev. Biol. Trop. 64 (2): 875-883. Epub 2016 June 01.
\end{abstract}

Key words: Atlantic Forest, Clarke \& Warwick's indices, conservation areas, jumping spiders.

Misiones rainforest (Northeastern Argentina) is bio-geographically linked with the Atlantic Forest of Brazil (Brown, Placci, \& Grau, 1993); represents the least fragmented remnant of the Upper Parana Atlantic Forest ecoregion (UPAF), including the Araucaria Moist Forest (AMF) (Olson et al., 2001; Placci \& Di Bitetti, 2006). In Argentina, UPAF + AMF have a high biodiversity and endemism only analogous with the Yungas rainforest in Northwestern of the country (Bertonatti \& Corcuera, 2000). With a surface of $27050 \mathrm{~km}^{2}$, Misiones rainforest represents about $1 \%$ of continental Argentina, but accumulates much of the country's biodiversity (Brown et al., 1993). In addition to the UPAF and AMF, in the Southern end of Misiones province there is another ecoregion: Southern Cone Mesopotamian Savanna (SCMS). There are prevailing soils for crops and forest plantations, predominantly a tropical savanna with flooded plains, wetlands and grasslands (Viglizzo, Frank, \& Carreño, 2006). Those ecoregions of Misiones have a suitable scenario for a high complementarity and diversity of species, certainly including spiders.

Misiones conservation efforts have been focused on the flora, bird and mammalian populations of its biome (Giraudo \& Povedano, 2004; Di Bitetti, Paviolo, \& De Angelo, 2006; Placci \& Di Bitetti, 2006; Gil \& Moreno, 2007; Paviolo, De Angelo, Di Blanco, \& Di Bitetti, 2008; Paviolo, Di Blanco, De Angelo, \& Di Bitetti, 2009; Di Bitetti, De Angelo, Di Blanco, 
\& Paviolo, 2010; Cruz, Paviolo, Bó, Thompson, \& Di Bitetti, 2014), but little is known about invertebrate fauna and its diversity at the community level. This irregular knowledge would hamper research, and needless to say, has important implications in terms of assessing the regional biodiversity. However, when it is assumed that there is a reasonably complete species inventory for a region, with a defined Linnean taxonomy for the species involved, such data represents an additional advantage since it allows assessments of regional biodiversity (Clarke \& Warwick, 1998; Magurran, 2004).

A taxonomically complete inventory of species, with good taxonomic resolution, is an advantageous feature that can be used in the analysis of species diversity and has great potential in setting conservation priorities, and support for environmental monitoring in forest areas (Vane-Wright, Humphries, \& Williams, 1991; Williams, Humphries, \& Vane-Wright, 1991; Warwick \& Clarke, 1995, 1998; Clarke \& Warwick, 1999). This facet of biodiversity can be easily assessed with Clarke and Warwick's taxonomic diversity indices, which take into account the taxonomical arrangement of species as a crude approximation to their evolutionary diversity (Warwick \& Clarke, 1995; Clarke \& Warwick, 1998), and is based on the idea that a community with closely related species is less biodiverse, than a similarly rich and even community, with low relatedness among species. Besides, this taxonomic information can be used to measure $\beta$-diversity, based on taxonomic dissimilarity coefficients for presence / absence data, regardless of the sampling effort (Warwick \& Clarke, 1995; Izsák \& Price, 2001; Bacaro, Ricotta, \& Mazzoleni, 2007). In that way, checklist or faunistic studies demonstrate a clear connection between basic taxonomy and biodiversity issues; and, as in other fields, these inventories provide an important source of quantitative compiled information concerning species diversity of several regions.

The most specious family within the Order Araneae is Salticidae, a mega-diverse group which is represented by 5814 described species, more than 600 genera in the world (World Spider Catalog, 2015) and at least 66 genera in Misiones, Argentina (Rubio, 2014). Jumping spiders are strongly influenced by habitat type (Uetz, 1991; Cumming \& Wesolowska, 2004; Rubio, 2015). Their abundance and species composition are affected by the structural complexity of vegetation, giving their site preferences for stalking and hunting prey (Hatley \& MacMahon, 1980; Whitmore, Slotow, Crouch, \& Dippenaar-Schoeman, 2002; Cumming \& Wesolowska, 2004; Tews et al., 2004; Tsai, Huang \& Tso, 2006). Also, jumping spiders are easily located due to their conspicuousness and high abundance in ecosystems. These features lead to consider this group as an appropriate model for biodiversity studies (Coddington \& Levi, 1991; New, 1999).

The Misiones salticid fauna is relatively well known; the last published inventory revealed that almost $52 \%$ of the Argentinean fauna of Salticidae inhabits this province (Rubio, 2014). Since this is the most relevant inventoried family, all available information on these spiders occurrence and distribution within Misiones, was used to generate the taxonomic diversity assessments included in this study. Hence, the objectives of this study were to assess the jumping spider richness, to analyze different ecoregional taxonomic diversities, and to evaluate their taxonomic differentiation ( $\beta$-diversity) among ecoregions in Misiones province.

\section{MATERIALS AND METHODS}

Species inventory: A total of 501 records of Salticidae species from Misiones province were used (Fig. 1). For this, a number of sources were used, most of which (68\%) were based on specimens from the arachnid collection of the Museo Argentino de Ciencias Naturales "Bernardino Rivadavia" (MACNAr, C. Scioscia). Other sources were the recent surveys of 2013, 2014 (23\%) deposited at the arachnid collection of the Instituto de Biologia Subtropical (IBSI-Ara, G. Rubio), 


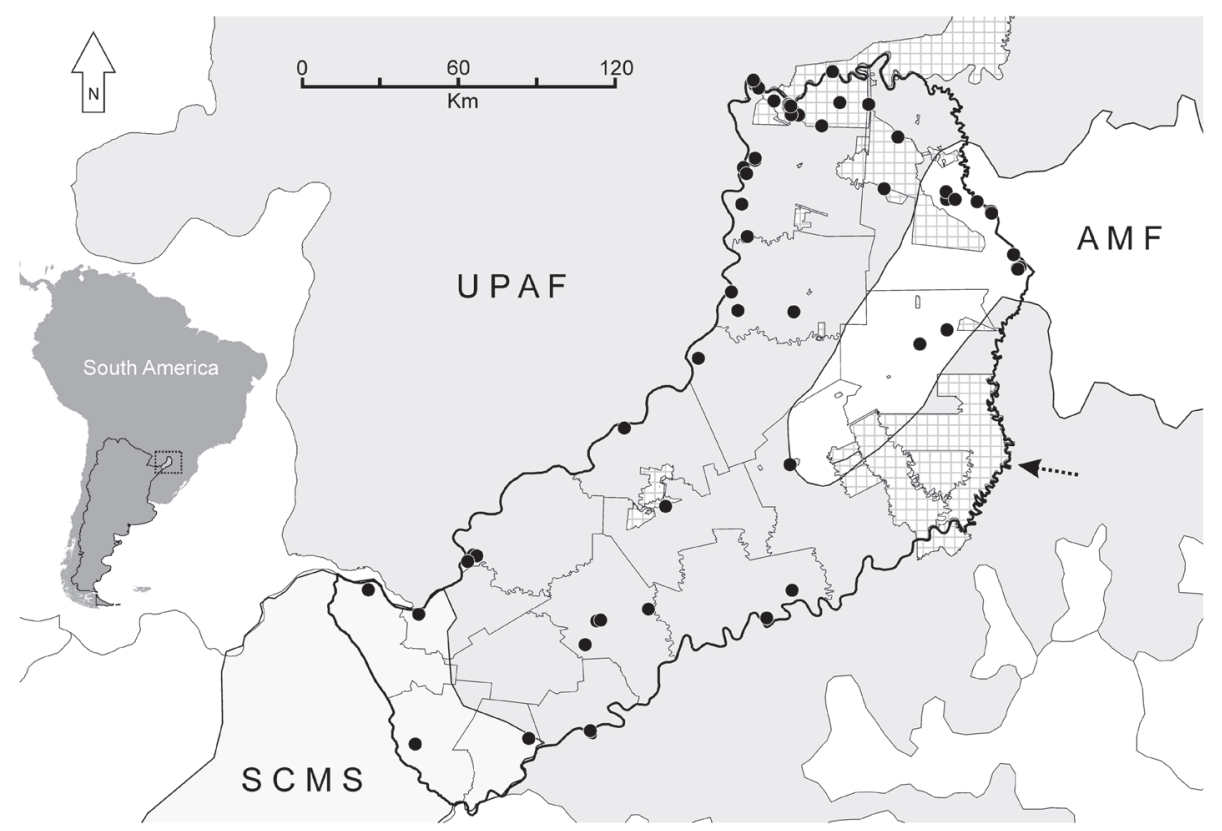

Fig. 1. Locality records of Salticidae species (dots) and extent of the ecoregions (UPAF: Upper Parana Atlantic Forest; AMF: Araucaria Moist Forest; SCMS: Southern Cone Mesopotamian Savanna) from Olson et al. (2001) in Misiones province, Argentina. Grid: conservation areas (arrow: Yabotí Biosphere Reserve). Inset: location of the map area in South America.

and available literature (9\%) including cited specimens from Museo de La Plata collection (MLP, L. Pereira) (Mello-Leitão, 1945; Pereira, Sutton, \& Ramírez, 1999). Specific identities were checked for consistency with the current taxonomic nomenclature in the World Spider Catalog (WSC, 2015) which was followed in every case. Subfamily classification of salticids was based on the following priority order: Maddison et al. (2014), Bodner and Maddison (2012), Maddison (2011), Maddison and Hedin (2003) and the Catalogue of Salticidae by Prószyński (2015). The details of the complete inventory can be seen in Rubio (2014).

Taxonomic diversity was assessed and compared between ecoregions: Upper Parana Atlantic Forest (UPAF), Araucaria Moist Forest (AMF), and Southern Cone Mesopotamian Savanna (SCMS). With the complete inventory of species I generated two measures called Average Taxonomic Distinctness $\left(\Delta^{+}\right)$ and Variation in Taxonomic Distinctness $(\Lambda+)$ (sensu Clarke \& Warwick, 1998, 2001). On one hand, $\Delta+$ takes into account the taxonomic level at which any two species are related and can be thought of as the average length -in the taxonomic tree- between any two randomly chosen species present in the assemblage (Warwick $\&$ Clarke, 1995; Magurran, 2004). Thus, $\Delta^{+}$ is a direct measure of $\alpha$-taxonomic diversity: a high value of $\Delta^{+}$reflects high taxonomic diversity (low relatedness among species). On the other hand, $\Lambda+$ reflects the degree to which certain taxa are over- or under-represented in assemblages. Therefore, $\Lambda+$ measures the unevenness in the taxonomic tree, and is thus complementary to the concept of taxonomic biodiversity: high taxonomic diversity would be expected for a community with an even distribution of species among the taxonomic levels and units, a situation that would result in a low value of $\Lambda+$

A simple linear scaling was used whereby the largest number of steps in the tree is set to $\omega$ $=100$. Also a randomization test $(1000$ random samples) was performed to detect differences in the taxonomic distinctness at each observed assemblage, from the expected values derived 
from the species pool (formed from the three ecoregions), taking into account the number of species of the assemblages (Clarke \& Warwick, 1998). The null hypothesis assumes that each assemblage contains species randomly selected from the pool and that it should therefore fall within the $95 \%$ confidence intervals. All the analyses of taxonomic diversity measures and randomization tests were performed using PRIMER (Clarke \& Gorley, 2001).

The utility of $\beta$-diversity is that it incorporates not only species richness, but also binary information about the higher-order taxonomic structure degree (relatedness/distances) between species assemblages; and is becoming increasingly recognized (Clarke \& Warwick, 1998; Izsák \& Price, 2001; Bacaro et al., 2007). Accordingly, two pairwise taxonomic dissimilarity coefficients were used: $\left(1-\Delta_{S}\right)$ proposed by Izsák and Price (2001), and $\left(1-\Delta_{T}\right)$ adjusted by Bacaro et al. (2007). The former obtained from the minimum taxonomic distances between any two species in different assemblages. Here, the concept of "taxonomic distance" is defined as the number of higher-level taxa in the Linnaean taxonomy between the species and the taxonomic level where a common ancestor exists (Bacaro et al., 2007). In this case the species are classified into genera, subfamilies and family (reaching four levels), the taxonomic distance is 0 for two individuals of the same species, 1 for two individuals of different species but same genus, 2 for two individuals of different genus but same subfamily, and so on. So, given two species assemblages, A and $\mathrm{B}$, the average minimum taxonomic distance (TD) between assemblage A and assemblage $\mathrm{B}$ is computed as follows TD $=\left(\sum_{i} w_{i A}+\sum_{j} w_{j B}\right)$
/ $\left(n_{A}+n_{B}\right)$, where $w_{i A}$ is the minimum taxonomic distance between species $i$ in assemblage $\mathrm{A}$ and all species in assemblage $\mathrm{B} ; w_{j B}$ is the minimum taxonomic distance between species $j$ in assemblage B and all species in assemblage $\mathrm{A}$, and $n_{A}$ and $n_{B}$ are the number of species in assemblages $\mathrm{A}$ and $\mathrm{B}$, respectively (Bacaro et al., 2007). The values of TD were transformed into a normalized measure as $\Delta_{S}=1-\mathrm{TD} /(L$ - 1) where $L$ is the number of taxonomic levels used for constructing the taxonomic tree (Izsák $\&$ Price, 2001). The second used coefficient $\left(1-\Delta_{T}\right)$ is simplified as $1-\left(\sum_{S h T} / \sum_{T}\right)$ where ${ }_{S h T}$ is the number of shared taxa, and ${ }_{T}$ is the total number of taxa (Bacaro et al., 2007). Above $80 \%$ of the variance in this taxonomic dissimilarity, is explained by the assemblage structure at the species level, while only the residual variance is explained by differences at higher-order taxonomic structure of the species assemblages (Bacaro et al., 2007).

The taxonomic distinctness index is a biologically and ecologically relevant measure of biodiversity due to its lack of dependence on sampling effort and having a statistical framework for the assessment of the significance of departure from expectation (Warwick \& Clarke, 1998).

\section{RESULTS}

Results showed that the salticid inventory of Misiones has differences in species richness among the evaluated ecoregions: most species were registered in UPAF (91 species) followed by AMF (53) and with the lowest value SCMS (28) (Table 1). Therefore, the knowledge about the distribution of salticids was somewhat

TABLE 1

$\alpha$-taxonomic diversity values of jumping spiders (Salticidae) for ecoregions at the Misiones Province, Argentina, according to the indices proposed by Clarke and Warwick (1998)

\begin{tabular}{lccc} 
Ecoregion & Species Richness & Average Taxonomic Distinctness $(\Delta+)$ & Variation in Taxonomic Distinctness $(\Lambda+)$ \\
UPAF & 91 & 56.51 & 107.46 \\
AMF & 53 & 55.87 & $131.50^{*}$ \\
SCMS & 28 & 57.54 & 75.69 \\
\hline
\end{tabular}

*: statistically significant different from the predicted value by a randomization test $(\mathrm{P}<0.05)$. UPAF: Upper Parana Atlantic Forest; AMF: Araucaria Moist Forest; SCMS: Southern Cone Mesopotamian Savanna. 
uneven; the nearly 500 records were not uniformly distributed throughout the province territory (Fig. 1): 338 records (43 non duplicate locality points) in UPAF, 97 (12) in AMF, and 66 (4) in SCMS.

a-taxonomic diversity: Was observed that the Average Taxonomic Distinctness $\left(\Delta^{+}\right)$ index had higher value of taxonomic spider diversity in SCMS than in UPAF and AMF in Misiones province, although not significantly different among the three ecoregions from the expected by random (Table 1; Fig. 2A). A different pattern was found for the index of Variation in Taxonomic Distinctness $(\Lambda+)$, for which AMF had higher value than UPAF and SCMS, and this value was statistically higher from the value calculated with the randomization test, i.e. the expected value (Table 1; Fig. 2B).

$\beta$-taxonomic diversity: A full assessment of the $\beta$-diversity among ecoregions $\left(1-\Delta_{S}\right.$ and $1-\Delta_{T}$ ) is shown in Table 2 . The proportions of shared species between SCMS and UPAF (or and AMF) were the lowest, i.e. greatest taxonomic distance. AMF and UPAF were the less taxonomically distant ecoregions (Table 2). The pattern of taxonomic dissimilarity for both coefficients was the same (Table 2).

\section{DISCUSSION}

The known distribution of salticids was uneven because not all the records were
TABLE 2

$\beta$-diversity based on taxonomic distance values of jumping spiders (Salticidae) between ecoregions at the Misiones Province, Argentina, according to the coefficients proposed by Clarke and Warwick (1998) and Izsák and Price (2001), and corrected by Bacaro et al. (2007)

\begin{tabular}{lll} 
& \multicolumn{1}{c}{ UPAF } & \multicolumn{1}{c}{ AMF } \\
AMF & $\mathrm{TD}=0.653$ & \multicolumn{1}{c}{-} \\
& $1-\Delta_{S}=0.217$ & \\
& $1-\Delta_{T}=0.469$ & $\mathrm{TD}=1.210$ \\
SCMS & $\mathrm{TD}=1.353$ & $1-\Delta_{S}=0.403$ \\
& $1-\Delta_{S}=0.451$ & $1-\Delta_{T}=0.717$ \\
\hline
\end{tabular}

TD: taxonomic distance; $1-\Delta_{S}$ : taxonomic dissimilarity; $1-\Delta_{T}$ : taxonomic dissimilarity (sensu Bacaro et al., 2007); UPAF: Upper Parana Atlantic Forest; AMF: Araucaria Moist Forest; SCMS: Southern Cone Mesopotamian Savanna.

uniformly distributed throughout the provincial territory. Probably this distribution data are not only indicating that some species may be under-collected, but also the consequence that some areas were not sampled, such as Yabotí Biosphere Reserve (central Eastern Misiones). The need to expand with new samples in other sub-sampled or unexplored areas of Misiones, remains essential. Nevertheless, the analysis showed well-structured communities due to taxonomic differences (at least in the savannas) and the great variety of forms within the province.
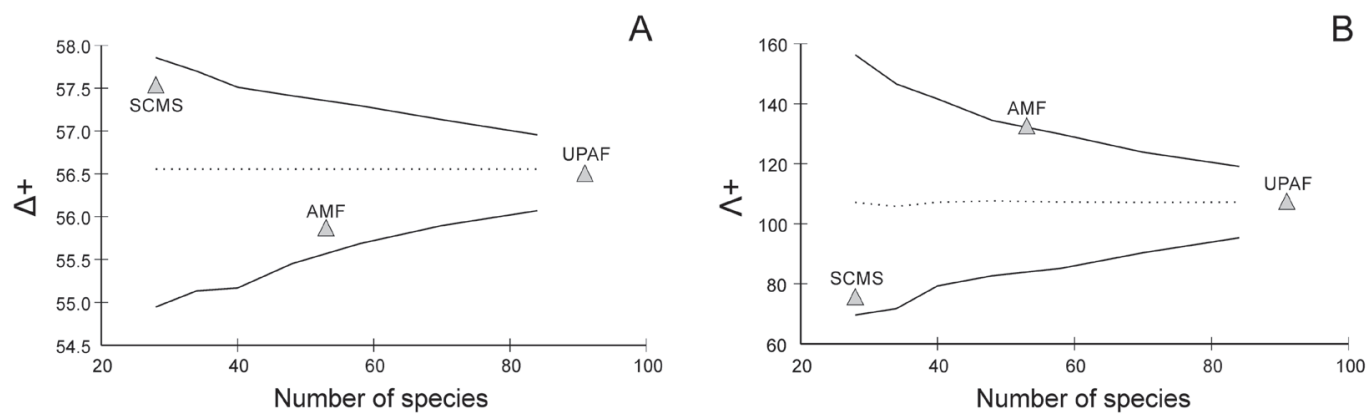

Fig. 2. Confidence funnel (95\%) for Average Taxonomic Distinctness (A) and Variation in Taxonomic Distinctness (B) of jumping spiders (Salticidae) for each ecoregion (UPAF: Upper Parana Atlantic Forest; AMF: Araucaria Moist Forest; SCMS: Southern Cone Mesopotamian Savanna) from Misiones Province, Argentina. 
The higher taxonomic diversity $(\Delta+)$ in the SCMS community and its implications in taxonomic relatedness for conservation priorities is an issue that should be studied in deep, given that SCMS has lower observed species richness representing a smaller sampling area in the province. The higher value of $\Lambda^{+}$ (Variation in Taxonomic Distinctness) would indicate an over- or under-representation of some taxa (Warwick \& Clarke, 1995; Magurran, 2004), and therefore the lower taxonomic diversity in AMF.

The relatively high taxonomic dissimilarity $\left(1-\Delta_{S}\right.$ and $\left.1-\Delta_{T}\right)$ is an indication that the three assemblages are distant, showing a variation in their vegetation habitat and/or bioclimatic characteristics as a possible reason (Coddington, Young, \& Coyle, 1996). These results are also supported by its location in quite different ecoregions of Misiones: forests (UPAF and AMF) vs. savanna (SCMS) (Olson et al., 2001; Placci \& Di Bitetti, 2006). These differences in salticid composition among ecoregions, $80 \%$ given by the species level and remaining by the higher-order taxonomic structure (sensu Bacaro et al., 2007), explained the significant contribution of $\beta$-taxonomic diversity to the whole regional jumping spider richness in Misiones province.

The salticids proved to be a suitable taxonomic group for this study, however, this does not mean that jumping spiders are considered a particularly essential taxonomic group for these ecosystems. Nevertheless, the importance of this taxon is that it offered a baseline approach model, and revealed that spider assemblages change according to different ecoregions.

Spider diversity in the Neotropical region is not yet well known, especially in the Argentinean subtropical forests where systematic fieldwork and data compilation were not undertaken until recent times (Avalos, Rubio, Bar, \& Damborsky, 2006; Avalos, Rubio, Bar, \& González, 2007; Avalos, Damborsky, Bar, Oscherov, \& Porcel, 2009; Rubio, Corronca, \& Damborsky, 2008; Rubio \& Moreno, 2010; Rubio, 2014). We began using this compiled information to conduct comparative studies of spider assemblages in order to contribute with baseline knowledge, after the CBD (Convention of Biological Diversity) guidelines signed by the Argentine government. In this long process, this study contributed and updated the salticid biodiversity information for the ecoregions of Misiones, Northeast Argentina, and provided reference data for future studies regarding management plans.

\section{ACKNOWLEDGMENTS}

I wish to thank to anonymous reviewers and Daisy Arroyo Mora for comments and corrections on this manuscript; to Carlo Ricotta and Julian Baigorria for your helps; to Carlos De Angelo for providing the layers of Misiones conservation areas. I thank also the following institutions and corresponding authorities: Fundación Vida Silvestre Argentina (FVSA), Administración de Parques Nacionales (APN), Centro de Investigaciones Antonia Ramos (CIAR), and Ministerio de Ecología y Recursos Naturales Renovables (MEyRNR) de la Provincia de Misiones. This contribution was supported by CONICET.

\section{RESUMEN}

Uso de inventario de arañas saltadoras (Araneae: Salticidae) como un indicador de diversidad taxonómica en Misiones, Argentina. Los estudios faunísticos, con un inventario de especies taxonómicamente completo, proveen una fuente importante de información compilada cuantitativa acerca de varias regiones. Esta información puede ser utilizada en análisis de diversidad y tiene gran potencial en el establecimiento de prioridades de conservación. En este estudio, yo utilicé la relativamente bien conocida fauna de arañas saltícidas de Misiones para generar índices de diversidad taxonómica de Clarke y Warwick. Para ello, la información de tres diversidades ecorregionales de saltícidos fue obtenida y analizada entre la Selva Atlántica del Alto Paraná (UPAF), el Bosque Húmedo de Araucaria (AMF), y la Sabana Mesopotámica del Cono Sur (SCMS). Fueron encontradas diferencias entre las tres ecorregiones de la provincia, principalmente en las sabanas del sur con respecto a las selvas del norte de Misiones. La mayoría de las especies fueron registradas en UPAF seguida por AMF, sin embargo la diversidad $\alpha$-taxonómica de saltícidos fue mayor en SCMS que en UPAF y AMF. La diversidad $\beta$-taxonómica mostró que 
las proporciones de especies compartidas entre SCMS y UPAF (o AMF) fueron las más bajas. La alta disimilitud taxonómica entre ecorregiones es un indicador de que los tres ensamblajes son distantes, mostrando una variación en la vegetación de su hábitat y/o características bioclimáticas como una posible razón. Sigue siendo esencial la necesidad de ampliar con nuevas muestras en áreas no- o sub-muestreadas de Misiones, sin embargo este estudio contribuye a la información acerca de los niveles de biodiversidad de la fauna de saltícidos en tres ecorregiones del nordeste de Argentina, y proporcionará datos de referencia para futuros planes de gestión.

Palabras clave: arañas saltadoras, áreas de conservación, índices de Clarke \& Warwick, Selva Atlántica.

\section{REFERENCES}

Avalos, G., Damborsky, M. P., Bar, M. E., Oscherov, E. B., \& Porcel E. (2009). Composición de la fauna de Araneae (Arachnida) de la Reserva provincial Iberá, Corrientes, Argentina. Revista de Biología Tropical, 57, 339-351.

Avalos, G., Rubio, G. D., Bar, M. E., \& Damborsky, M. P. (2006). Lista preliminar de la araneofauna (Arachnida: Araneae) del Centro-Norte de la Provincia de Corrientes, Argentina. Revista Ibérica de Aracnología, 13, 189-194.

Avalos, G., Rubio, G. D., Bar, M. E., \& González, A. (2007). Arañas (Arachnida, Araneae) asociadas a dos bosques degradados del Chaco húmedo en Corrientes, Argentina. Revista de Biología Tropical, 55, 899-909.

Bacaro, G., Ricotta, C., \& Mazzoleni, S. (2007). Measuring beta-diversity from taxonomic similarity. Journal of Vegetation Science, 18, 793-798.

Bertonatti, C., \& Corcuera, J. (2000). Situación ambiental Argentina 2000. Buenos Aires, Argentina: Fundación Vida Silvestre Argentina.

Bodner, M. R., \& Maddison, W. P. (2012). The biogeography and age of salticid spider radiations (Araneae: Salticidae). Molecular Phylogenetics and Evolution, 65, 213-240.

Brown, A. D., Placci, L. G., \& Grau, H. R. (1993). Ecología y diversidad de las selvas subtropicales de la Argentina. In F. Goin \& F. Goñi (Eds.), Elementos de política ambiental (pp. 215-222). Buenos Aires, Argentina: H. Cámara de Diputados.

Clarke, K. R., \& Gorley, R. N. (2001). PRIMER v5: User manual/tutorial. Plymouth: Plymouth Marine Laboratory.
Clarke, K. R., \& Warwick, R. M. (1998). A taxonomic distinctness index and its statistical properties. Journal of Applied Ecology, 35, 523-531.

Clarke, K. R., \& Warwick, R. M. (1999). The taxonomic distinctness measure of biodiversity: weighing of step lengths between hierarchical levels. Marine Ecology Progress Series, 184, 21-29.

Clarke, K. R., \& Warwick, R. M. (2001). Change in marine communities: An approach to statistical analysis and interpretation 2nd ed. Plymouth: PRIMER-E.

Coddington, J. A., \& Levi, H. (1991). Systematics and evolution of spiders. Annual Review of Ecology and Systematics, 22, 111-128.

Coddington, J. A., Young, L. H., \& Coyle, F. A. (1996). Estimating spider species richness in a Southern Appalachian cove hardwood forest. Journal of Arachnology, 24, 111-128.

Cruz, P., Paviolo, A., Bó, R. F., Thompson, J. J., \& Di Bitetti, M. S. (2014). Daily activity patterns and habitat use of the lowland tapir (Tapirus terrestris) in the Atlantic Forest. Mammalian Biology, 79, 376-383.

Cumming, M. S., \& Wesołowska, W. (2004). Habitat separation in a species-rich assemblage of jumping spiders (Araneae: Salticidae) in a suburban study site in Zimbabwe. Journal of Zoology, 262, 1-10.

Di Bitetti, M. S., De Angelo, C. D., Di Blanco, Y. E., \& Paviolo, A. (2010). Niche partitioning and species coexistence in a Neotropical felid assemblage. Acta Oecologica, 36, 403-412.

Di Bitetti, M. S., Paviolo, A., \& De Angelo, C. (2006). Density, habitat use and activity patterns of ocelots (Leopardus pardalis) in the Atlantic Forest of Misiones, Argentina. Journal of Zoology, 270, 153-163.

Gil, G. \& Moreno, C. M. (2007). Los análisis de complementariedad aplicados a la selección de reservas de la biosfera: efecto de la escala. In G. Halffter, S. Guevara, \& A. Melic (Eds.), Hacia una cultura de conservación de la diversidad biológica (pp. 63-70). Zaragoza, España: Monografías Tercer Milenio.

Giraudo, A. R. \& Povedano, H. (2004). Avifauna de la región biogeográfica Paranaense o Atlántica Interior de Argentina: biodiversidad, estado del conocimiento y conservación. Miscelánea, 12, 331-348.

Hatley, C. L., \& MacMahon, J. A. (1980). Spider community organization: Seasonal variation and the role of vegetation architecture. Environmental Entomology, 9, 632-639. 
Izsák, C., \& Price, R. G. (2001). Measuring b-diversity using a taxonomic similarity index, and its relation to spatial scale. Marine Ecology Progress Series, $215,69-77$.

Maddison, W. P. (2011). Salticidae. Jumping Spider. The Tree of Life Web Project. Retrieved from http:// tolweb.org/Salticidae/2677/2011.10.12

Maddison, W. P., \& Hedin, M. C. (2003). Jumping spider phylogeny (Araneae: Salticidae). Invertebrate Systematics, 17, 529-549.

Maddison, W. P., Li, D. Q., Bodner, M., Zhang, J. X., Xu, X., Liu, Q. Q., \& Liu, F. X. (2014). The deep phylogeny of jumping spiders (Araneae, Salticidae). ZooKeys, 440, 57-87.

Magurran, A. E. (2004). Measuring biological diversity. United Kingdom: Oxford, Blackwell Science Ltd.

Mello-Leitão, C. F. (1945). Arañas de Misiones, Corrientes y Entre Ríos. Revista del Museo de La Plata, 4, 213-302.

New, T. R. (1999). Untangling the web: spiders and the challenges of invertebrate conservation. Journal of Insect Conservation, 3, 251-256.

Olson, D. M., Dinerstein, E., Wikramanayake, E. D., Burgess, N. D., Powell, G. V. N., Underwood, E. C., ... Kassem, K. (2001). Terrestrial ecoregions of the world: a new map of life on Earth. BioScience, 51, 933-938. Retrieved from http://www.worldwildlife. org/science/ecoregions/terrestrial.cfm

Paviolo, A., De Angelo, C. D., Di Blanco, Y. E., \& Di Bitetti, M. S. (2008). Jaguar Panthera onca population decline in the Upper Paraná Atlantic Forest of Argentina and Brazil. Oryx, 42, 554-561.

Paviolo, A., Di Blanco, Y. E., De Angelo, C. D., \& Di Bitetti, M. S. (2009). Protection affects the abundance and activity patterns of pumas in the Atlantic Forest. Journal of Mammalogy, 90, 926-934.

Pereira, L. A., Sutton, C. A., \& Ramírez, M. J. (1999). Catálogo de tipos de Araneae (Arachnida) del Museo de La Plata. Neotrópica, 45, 77-100.

Placci, G. \& Di Bitetti, M. (2006). Situación ambiental en la Ecorregión del Bosque Atlántico del Alto Paraná (selva paranaense). In A. D. Brown, U.
Martínez Ortíz, M. Acerbi, \& J. Corcuera (Eds.), La situación ambiental argentina 2005 (pp. 195-225). Buenos Aires, Argentina: Fundación Vida Silvestre Argentina.

Prószyński, J. (2015). Monograph of Salticidae (Araneae) of the World. Retrieved from http://www.peckhamia. com/salticidae/

Rubio, G. D. (2014). Baseline richness of Salticidae (Araneae) from Misiones, Argentina. Peckhamia, 118.1, $1-21$.

Rubio, G. D. (2015). Diversidad de arañas (Araneae, Araneomorphae) en la selva de montaña: un caso de estudio en las Yungas Argentinas. Graellsia, 71(2), 1-21.

Rubio, G. D., \& Moreno, C. E. (2010). Orb-weaving spider diversity in the Iberá marshlands (Argentina). Neotropical Entomology, 39, 496-505.

Rubio, G. D., Corronca, J. A., \& Damborsky, M. P. (2008). Do spider diversity and assemblage change on different contiguous habitats? A case on protected habitats of Humid Chaco Ecoregion, North-East of Argentina. Environmental Entomology, 37, 419-430.

Tews, J., Brose, U., Grimm, V., Tielbörger, K., Wichmann, M. C., Schwager, M., \& Jeltsch, F. (2004). Animal species diversity driven by habitat heterogeneity/ diversity: the importance of keystone structures. Journal of Biogeography, 31, 79-92.

Tsai, Z. I., Huang, P. S., \& Tso, I. M. (2006). Habitat management by aboriginals promotes high spider diversity on an Asian tropical island. Ecography, 29, 84-94.

Uetz, G. W. (1991). Habitat structure and spider foraging. In S. S. Bell, E. D. McCoy, \& H. R. Mushinsky (Eds.), Habitat structure. The physical arrangement of objects in space (pp. 325-348). London: Chapman and Hall.

Vane-Wright, R. I., Humphries, C. J., \& Williams, P. H. (1991). What to protect? Systematics and the agony of choice. Biological Conservation, 55, 235-254.

Viglizzo, E. F., Frank, F. C., \& Carreño, L. (2006). Situación ambiental en las Ecorregiones Pampa y Campos y Malezales. In A. D. Brown, U. Martínez Ortíz, M. Acerbi, \& J. Corcuera (Eds.), La situación ambiental argentina 2005 (pp. 261-278). Buenos Aires, Argentina: Fundación Vida Silvestre Argentina. 
Warwick, R. M., \& Clarke, K. R. (1995). New "biodiversity" measures reveal a decrease in taxonomic distinctness with increasing stress. Marine Ecology Progress Series, 129, 301-305.

Warwick, R. M., \& Clarke, K. R. (1998). Taxonomic distinctness and environmental assessment. Journal of Applied Ecology, 35, 532-543.

Whitmore, C., Slotow, R., Crouch, T. E., \& Dippenaar-Schoeman, A. S. (2002). Diversity of spiders
(Araneae) in a savanna reserve, Northern Province, South Africa. Journal of Arachnology, 30, 344-356.

Williams, P. H., Humphries, C. J., \& Vane-Wright, R. I. (1991). Measuring biodiversity: taxonomic relatedness for conservation priorities. Australian Systematic Botany, 4, 665-679.

WSC. (2015). World Spider Catalog. Natural History Museum Bern. Retrieved from http://wsc.nmbe.ch 
